\title{
Influence of check dams on debris-flow run-out intensity
}

\author{
A. Remaître ${ }^{1}$, Th. W. J. van Asch ${ }^{2}$, J.-P. Malet ${ }^{1}$, and O. Maquaire ${ }^{3}$ \\ ${ }^{1}$ IPGS, CNRS UMR 7516, School and Observatory of Earth Sciences, University Louis Pasteur, Strasbourg, France \\ ${ }^{2}$ Utrecht University, Faculty of Geosciences, Utrecht, The Netherlands \\ ${ }^{3}$ GEOPHEN, CNRS UMR 6554, University of Caen Basse-Normandie, Caen, France
}

Received: 21 February 2008 - Revised: 31 October 2008 - Accepted: 13 November 2008 - Published: 12 December 2008

\begin{abstract}
Debris flows are very dangerous phenomena claiming thousands of lives and millions of Euros each year over the world. Disaster mitigation includes nonstructural (hazard mapping, insurance policies), active structural (drainage systems) and passive structural (check dams, stilling basins) countermeasures. Since over twenty years, many efforts are devoted by the scientific and engineering communities to the design of proper devices able to capture the debris-flow volume and/or break down the energy. If considerable theoretical and numerical work has been performed on the size, the shape and structure of check dams, allowing the definition of general design criteria, it is worth noting that less research has focused on the optimal location of these dams along the debris-flow pathway.

In this paper, a methodological framework is proposed to evaluate the influence of the number and the location of the check dams on the reduction of the debris-flow intensity (in term of flow thickness, flow velocity and volume). A debris-flow model is used to simulate the run-out of the debris flow. The model uses the Janbu force diagram to resolve the force equilibrium equations; a bingham fluid rheology is introduced and represents the resistance term. The model has been calibrated on two muddy debris-flow events that occurred in 1996 and 2003 at the Faucon watershed (South French Alps).

Influence of the check dams on the debris-flow intensity is quantified taking into account several check dams configurations (number and location) as input geometrical parameters. Results indicate that debris-flow intensity is decreasing with the distance between the source area and the first check dams. The study demonstrates that a small number of check dams located near the source area may decrease substantially the debris-flow intensity on the alluvial fans.
\end{abstract}

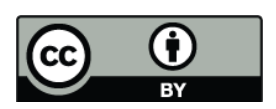

Correspondence to: A. Remaître (alexandre.remaitre@eost.u-strasbg.fr)

\section{Introduction}

Debris flows are a common type of mass movement in mountainous areas; they consist of fully saturated mixtures of water, sediment and debris (Iverson, 1997) that can travel, in a series of surges, several kilometres. Debris flows are widely recognized as one of the dominant geomorphic processes in steep mountainous terrain (Pierson, 1980; Costa, 1984; Johnson and Rodine, 1984; Takahashi, 1991; Scott et al., 1995; Corominas et al., 1996; Hungr et al., 2001; VanDine and Bovis, 2002; Godt adn Coe, 2007).

From a practical point of view, several analyses were conducted through a "temporal" approach to understand the triggering mechanisms and associated rainfall thresholds. These analyses were based on empirical hydrological correlations and pointed out a rather wide range of rainfall thresholds for several study areas (e.g. Campbell, 1974, 1975; Lumb, 1975; Okuda et al., 1980; Caine, 1980; Crozier and Eyles, 1980; Cannon and Ellen, 1985; Wieczorek, 1987). Other studies were conducted through a "spatial approach" in order to define the areas which could potentially trigger a debris flow (the susceptibility) (Montgomery and Dietrich, 1994; Iovine et al., 2003; Hürlimann et al., 2006; Guinau et al., 2007).

Moreover, unlike other types of landslides, the evaluation of the hazard requires, besides the prediction of the time occurrence and of the source material location, the assessment of the run-out susceptibility (e.g. O'Brien et al., 1993; Ayotte and Hungr, 2000; Laigle and Marchi, 2000; D'Ambrosio et al., 2007). Run-out distances of debris flows are strongly controlled both by the rheological behaviour of the material and the topography of the debris-flow track (Ancey, 2007). Considering this last point, one of the most important mitigation works in order to reduce the debris-flow impact consists to modify the topography of the debris-flow track by building check-dams along the torrential pathway. If considerable theoretical and numerical works have been performed on the size, shape and structure of torrential check dams,

Published by Copernicus Publications on behalf of the European Geosciences Union. 


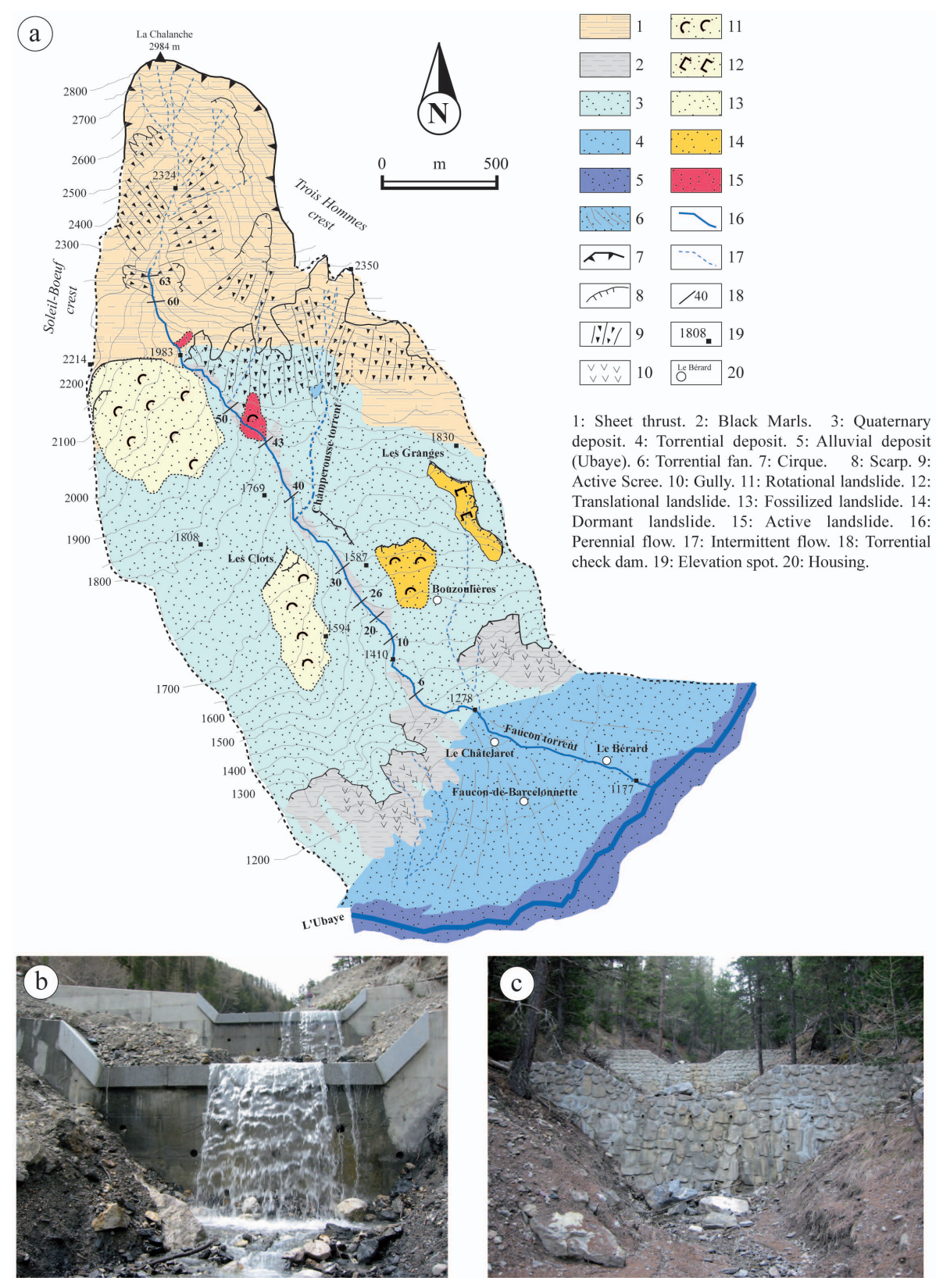

Fig. 1. Morphological sketch of the Faucon watershed (a), photograph of a concrete check dam (b), photograph of masonry check dam (c).

allowing the definition of general design criteria (Johnson and McCuen, 1989; Couvert et al., 1991; Armanini and Scotton, 1992; Deymier et al., 1994; Miyazawa et al., 2003), it is worth noting that less research has focused on the optimal number and location of these dams along the debris-flow pathway.

The aim of this paper is to analyse with a simple numerical model the effect of check dams on the debris-flow intensity (in terms of flow height, velocity and volume) according several configurations (number of check dams, location).

\section{Description of the test site and characteristics of the 2003 debris flow}

\subsection{The Faucon torrent}

The Faucon torrent $\left(44^{\circ} 25^{\prime} \mathrm{N}, 6^{\circ} 40^{\prime} \mathrm{E}\right)$ evolves in a steep forested watershed with an area of $10.5 \mathrm{~km}^{2}$ which rises to $2984 \mathrm{~m}$ a.s.l. (Fig. 1a). Local slopes are steeper than $25^{\circ}$, reaching $80^{\circ}$ at the highest parts of the massif which consist of two sheet thrusts of faulted sandstones and calcareous sandstones. Lower slopes consist of Callovo-Oxfordian black marls, covered by various Quaternary deposits chara- 


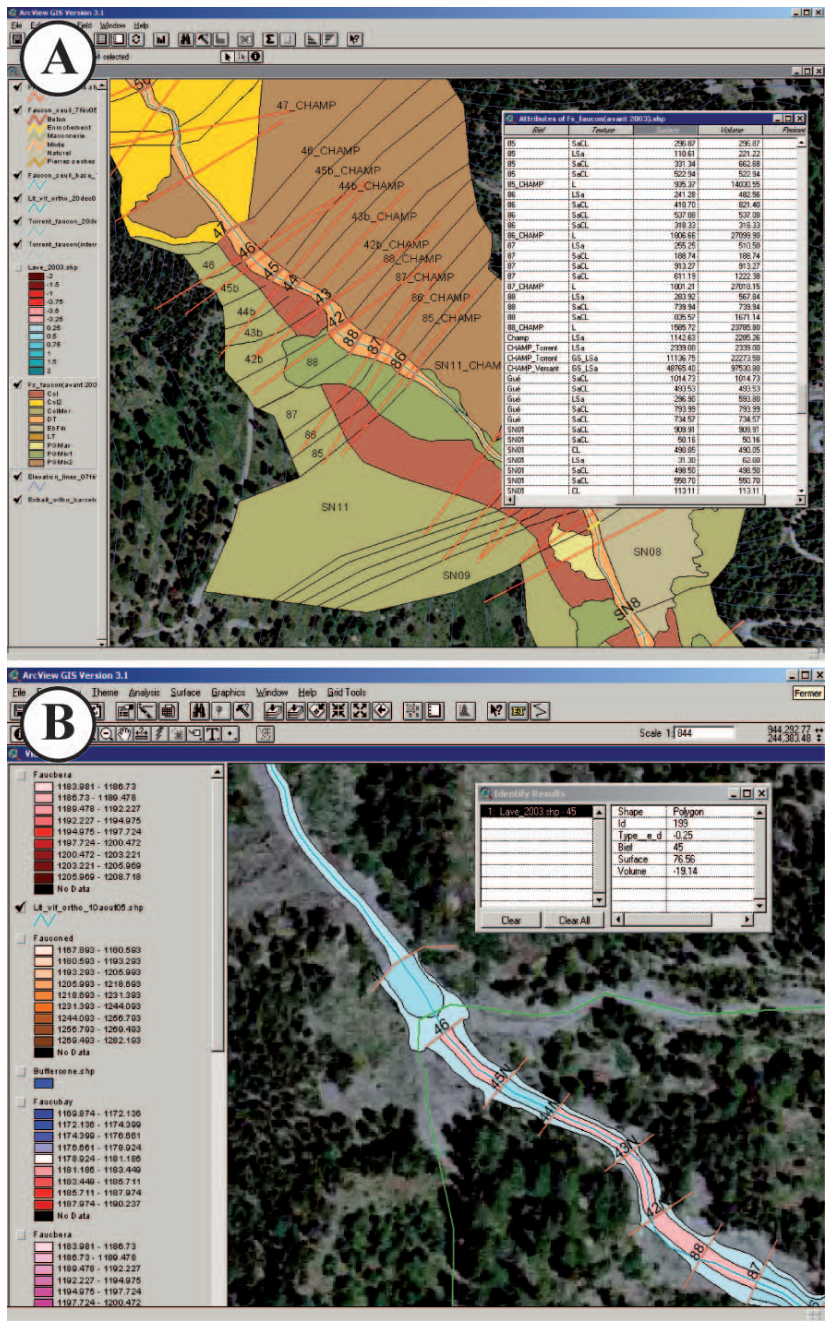

Fig. 2. GIS database of the Faucon torrent. (a) Torrential stretches characteristics, (b) Morphology of the 2003 debris flow (height of deposits and scouring depth).

cterized by a sandy-silt matrix, may include boulders up to $1-2 \mathrm{~m}$ in size and are between 3 and $15 \mathrm{~m}$ thick. The incised channel has an average slope of about $20^{\circ}$, ranging from $35^{\circ}$ in the headwater basin to $3^{\circ}$ on the alluvial fan, and is approximately $5500 \mathrm{~m}$ in length. The Faucon torrent has formed a $2 \mathrm{~km}^{2}$ debris-fan that spreads across the Ubaye valley floor. The fan slope gradient ranged from 4 to $9^{\circ}$ and is made mostly of cohesionless and high-permeable debris (debris-flows strata and/or torrent deposits).

Since 1850, fourteen major debris flows have occurred in the Faucon torrent. In order to prevent flooding, authorities have built a hundred check dams on the torrent since the 1890's; but only a half of them are still efficient. Two main types of check dams can be observed: concrete check dams (Fig. 1b) and masonry check dams (Fig. 1c). The last major events occurred in 1996 (Remaître et al., 2005a, b) and

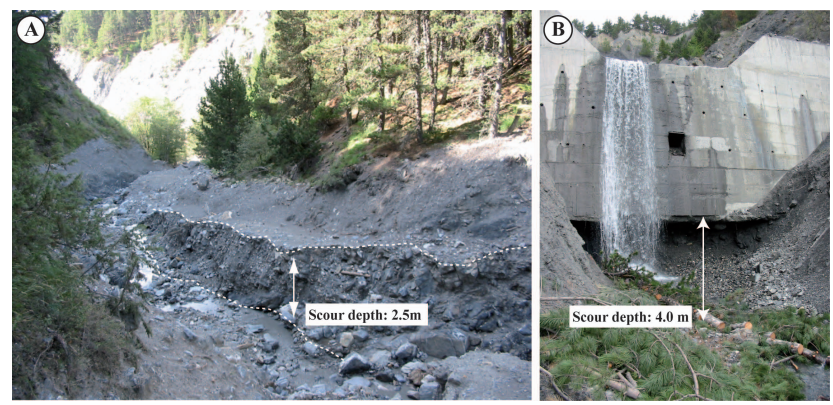

Fig. 3. Morphology of the scouring zones after the 2003 debris-flow event at the Faucon torrent. (a) View of a scoured stretch, (b) View of a strong scouring at the toe of a check dam.

in 2003 (Remaître, 2006; Remaître et al., 2008). A GIS database of the check dams has been built. For each dam, several characteristics have been recorded like the type, the size, and the year of construction (Fig. 2a). A sample of the database is presented in Table 1; the complete database is available on request.

\subsection{Kinematics of the 2003 debris flow}

The 2003 debris flow has been triggered on two specific spots on the East flank of the Faucon watershed: the Trois Hommes area, and the upper part of the Champerousse torrent (Fig. 6). For both cases, the morphology of the source area corresponds to a strong incision in scree slopes. In order to facilitate the sediment budget estimation, a GIS map of the morphology of the debris-flow (height of deposits and scouring depth) has been built (Fig. 2b). The average depth of the incision is about $2 \mathrm{~m}$; the total volume of the debris flow for the source areas is estimated to be in the range from 7500 to $9500 \mathrm{~m}^{3}$. Channel scour is responsible for the important difference between the $7500-9500 \mathrm{~m}^{3}$ of the two source areas and the $60000 \mathrm{~m}^{3}$ that spread over the fan (Remaitre, 2006). The total length of the debris-flow track is about $3500 \mathrm{~m}$, with a slope gradient of about $20^{\circ}$. Considering both the triggered and the deposited volumes and the length of the debris-flow track, the channel scour rate per metre amounts to $15 \mathrm{~m}^{3} \mathrm{~m}^{-1}$. This value is in agreement with values observed by other authors in various lithological environments (Hungr et al., 1984; Jibson, 1989; Jakob et al., 2000). Observations of the channel after the event indicate that the scour depth ranges between 0.5 and $4 \mathrm{~m}$ (Fig. 3a and b). The most intense scour depth was observed at the toe of some check dams, resulting from regressive channel erosion (Fig. 3b). The material deposited in the channel consisted mostly of clast-rich, slightly bouldery, sandy, muddy gravel, with the clast-rich and coarser fractions of this facies fringing the lobe margins and the top of the levees, where fine boulders and cobbles are concentrated. 
Table 1. Characteristics of the Faucon check dams before the 2003 debris flow.

\begin{tabular}{|c|c|c|c|c|c|c|c|c|}
\hline$N^{\circ}$ & Type & $\begin{array}{r}\text { Distance to Dam } 1 \\
(\mathrm{~m})\end{array}$ & $\begin{array}{r}\text { Toe elevation } \\
(\mathrm{m})\end{array}$ & $\begin{array}{r}\text { Top elevation } \\
(\mathrm{m})\end{array}$ & $\begin{array}{r}\text { Height } \\
\text { (m) }\end{array}$ & $\begin{array}{r}\text { Width min. } \\
\text { (m) }\end{array}$ & $\begin{array}{r}\text { Width max. } \\
(\mathrm{m})\end{array}$ & Status \\
\hline 1 & Concrete & 0 & 1271 & 1272 & 1.80 & 8.00 & 12.00 & Good \\
\hline 2 & Concrete & 312 & 1311 & 1318 & 7.00 & 2.80 & 20.00 & Good \\
\hline 3 & Masonry & 345 & 1319 & 1320 & 0.50 & 3.00 & 18.00 & Good \\
\hline 4 & Concrete & 357 & 1321 & 1330 & 8.70 & 8.20 & 29.80 & Good \\
\hline 5 & Concrete & 426 & 1334 & 1344 & 9.00 & 5.00 & 19.50 & Good \\
\hline 6 & Concrete & 486 & 1348 & 1349 & 1.00 & 8.00 & 8.00 & Good \\
\hline 7 & Concrete & 500 & 1350 & 1356 & 5.80 & 8.80 & 25.00 & Good \\
\hline 8 & Concrete & 560 & 1361 & 1371 & 9.40 & 6.00 & 16.40 & Good \\
\hline 9 & Concrete & 583 & 1374 & 1377 & 3.00 & 5.00 & 18.00 & Good \\
\hline 10 & Concrete & 596 & 1376 & 1377 & 0.50 & 5.00 & 11.00 & Buried \\
\hline 11 & Concrete & 616 & 1378 & 1381 & 2.70 & 3.10 & 11.90 & Damaged \\
\hline 12 & Concrete & 706 & 1392 & 1400 & 7.70 & 7.20 & 23.00 & Damaged \\
\hline 13 & Concrete & 760 & 1405 & 1414 & 8.80 & 6.00 & 24.00 & Damaged \\
\hline 14 & Concrete & 787 & 1415 & 1423 & 8.00 & 5.20 & 19.00 & Damaged \\
\hline 15 & Masonry & 809 & 1426 & 1427 & 1.00 & 5.00 & 5.00 & Destroyed \\
\hline 16 & Masonry & 815 & 1427 & 1427 & 0.00 & 5.00 & 5.00 & Destroyed \\
\hline 17 & Masonry & 854 & 1435 & 1435 & 0.00 & 4.00 & 4.00 & Destroyed \\
\hline 18 & Masonry & 947 & 1460 & 1463 & 3.00 & 5.50 & 5.50 & Destroyed \\
\hline 19 & Masonry & 978 & 1469 & 1469 & 0.00 & 4.20 & 4.20 & Destroyed \\
\hline 20 & Masonry & 1000 & 1477 & 1477 & 0.00 & 4.00 & 4.00 & Destroyed \\
\hline 21 & Masonry & 1006 & 1483 & 1483 & 0.00 & 4.00 & 4.00 & Destroyed \\
\hline 22 & Masonry & 1024 & 1490 & 1498 & 7.80 & 11.50 & 29.00 & Damaged \\
\hline 23 & Masonry & 1038 & 1498 & 1503 & 4.30 & 6.00 & 20.50 & Damaged \\
\hline 24 & Masonry & 1064 & 1507 & 1510 & 2.50 & 3.50 & 9.00 & Damaged \\
\hline 25 & Concrete & 1157 & 1525 & 1530 & 4.60 & 4.50 & 12.50 & Damaged \\
\hline 26 & Concrete & 1164 & 1531 & 1535 & 4.00 & 6.00 & 16.00 & Good \\
\hline 27 & Concrete & 1169 & 1536 & 1538 & 1.80 & 7.50 & 19.00 & Good \\
\hline 28 & Masonry & 1186 & 1539 & 1541 & 1.60 & 1.50 & 3.50 & Destroyed \\
\hline 29 & Masonry & 1219 & 1543 & 1549 & 6.00 & 6.70 & 10.40 & Good \\
\hline 30 & Concrete & 1248 & 1548 & 1557 & 9.50 & 6.00 & 16.40 & Good \\
\hline 31 & Masonry & 1311 & 1566 & 1569 & 3.00 & 3.50 & 13.00 & Good \\
\hline 32 & Concrete & 1334 & 1568 & 1574 & 5.20 & 4.50 & 16.50 & Good \\
\hline 33 & Concrete & 1372 & 1578 & 1584 & 5.50 & 5.50 & 16.00 & Good \\
\hline 34 & Concrete & 1397 & 1585 & 1588 & 2.70 & 5.00 & 18.00 & Good \\
\hline 35 & Concrete & 1562 & 1623 & 1628 & 5.00 & 10.00 & 20.00 & Good \\
\hline 36 & Concrete & 1567 & 1628 & 1630 & 2.00 & 10.00 & 20.00 & Good \\
\hline 37 & Concrete & 1585 & 1632 & 1634 & 2.10 & 12.00 & 22.00 & Good \\
\hline 38 & Masonry & 1625 & 1635 & 1635 & 0.00 & 4.00 & 15.00 & Destroyed \\
\hline 39 & Masonry & 1775 & 1667 & 1667 & 0.00 & 4.00 & 4.00 & Destroyed \\
\hline 40 & Masonry & 1785 & 1668 & 1668 & 0.00 & 5.00 & 5.00 & Destroyed \\
\hline 41 & Masonry & 1809 & 1672 & 1675 & 2.60 & 6.00 & 14.60 & Damaged \\
\hline 42 & Concrete & 2000 & 1704 & 1712 & 8.50 & 7.00 & 27.00 & Good \\
\hline 43 & Masonry & 2021 & 1711 & 1712 & 1.40 & 9.00 & 22.00 & Buried \\
\hline 44 & Masonry & 2042 & 1715 & 1715 & 0.00 & 11.00 & 25.00 & Destroyed \\
\hline 45 & Masonry & 2366 & 1777 & 1777 & 0.00 & 25.00 & 25.00 & Destroyed \\
\hline 46 & Masonry & 2373 & 1780 & 1780 & 0.00 & 25.00 & 25.00 & Destroyed \\
\hline 47 & Masonry & 2410 & 1788 & 1788 & 0.00 & 10.00 & 10.00 & Destroyed \\
\hline 48 & Concrete & 2514 & 1813 & 1816 & 2.80 & 5.00 & 16.50 & Good \\
\hline 49 & Concrete & 2524 & 1817 & 1819 & 2.70 & 5.30 & 21.00 & Good \\
\hline 50 & Concrete & 2545 & 1821 & 1825 & 3.50 & 5.00 & 18.60 & Good \\
\hline 51 & Concrete & 2562 & 1825 & 1828 & 3.00 & 5.00 & 16.50 & Good \\
\hline 52 & Concrete & 2579 & 1828 & 1830 & 2.40 & 5.00 & 25.00 & Good \\
\hline 53 & Concrete & 2597 & 1833 & 1837 & 3.20 & 5.00 & 18.00 & Good \\
\hline 54 & Concrete & 2621 & 1840 & 1842 & 3.10 & 5.00 & 19.00 & Good \\
\hline 55 & Concrete & 2637 & 1845 & 1847 & 1.40 & 5.00 & 14.70 & Good \\
\hline
\end{tabular}


Table 1. Continued.

\begin{tabular}{|c|c|c|c|c|c|c|c|c|}
\hline$N^{\circ}$ & Type & $\begin{array}{l}\text { Distance to Dam } 1 \\
\text { (m) }\end{array}$ & $\begin{array}{l}\text { Toe elevation } \\
\text { (m) }\end{array}$ & $\begin{array}{l}\text { Top elevation } \\
\text { (m) }\end{array}$ & $\begin{array}{l}\text { Height } \\
\text { (m) }\end{array}$ & $\begin{array}{l}\text { Width min. } \\
\text { (m) }\end{array}$ & $\begin{array}{l}\text { Width max. } \\
\text { (m) }\end{array}$ & Status \\
\hline 56 & Concrete & 2658 & 1848 & 1852 & 3.40 & 5.00 & 15.50 & Good \\
\hline 57 & Concrete & 2683 & 1851 & 1857 & 5.50 & 6.00 & 31.00 & Good \\
\hline 58 & Concrete & 2806 & 1882 & 1886 & 3.90 & 5.00 & 12.00 & Good \\
\hline 59 & Concrete & 2824 & 1887 & 1890 & 3.50 & 5.00 & 29.00 & Good \\
\hline 60 & Masonry & 2870 & 1895 & 1895 & 0.00 & 25.00 & 25.00 & Destroyed \\
\hline 61 & Masonry & 3114 & 1952 & 1954 & 3.00 & 6.00 & 15.00 & Damaged \\
\hline 62 & Masonry & 3364 & 2031 & 2032 & 1.00 & 8.20 & 15.00 & Damaged \\
\hline 63 & Masonry & 3383 & 2035 & 2035 & 0.00 & 8.50 & 12.00 & Destroyed \\
\hline 64 & Masonry & 3454 & 2050 & 2051 & 1.00 & 9.00 & 18.50 & Damaged \\
\hline 65 & Masonry & 3470 & 2053 & 2054 & 1.50 & 13.00 & 16.80 & Damaged \\
\hline 66 & Masonry & 3544 & 2071 & 2074 & 2.00 & 3.50 & 3.50 & Damaged \\
\hline 67 & Masonry & 3645 & 2093 & 2095 & 2.20 & 9.00 & 15.00 & Damaged \\
\hline 68 & Masonry & 3661 & 2101 & 2101 & 0.00 & 11.70 & 29.00 & Destroyed \\
\hline 69 & Masonry & 3681 & 2103 & 2106 & 3.00 & 11.00 & 25.00 & Damaged \\
\hline 70 & Masonry & 3770 & 2126 & 2126 & 0.00 & 4.00 & 7.00 & Destroyed \\
\hline 71 & Masonry & 3776 & 2127 & 2130 & 2.50 & 8.00 & 15.00 & Damaged \\
\hline 72 & Masonry & 3807 & 2135 & 2135 & 0.00 & 12.50 & 12.50 & Destroyed \\
\hline 73 & Masonry & 3825 & 2141 & 2143 & 2.20 & 4.50 & 12.00 & Destroyed \\
\hline 74 & Masonry & 3842 & 2145 & 2149 & 3.50 & 6.00 & 18.00 & Damaged \\
\hline 75 & Masonry & 3886 & 2158 & 2162 & 4.00 & 9.00 & 15.00 & Damaged \\
\hline 76 & Masonry & 3898 & 2163 & 2167 & 4.00 & 4.50 & 18.50 & Good \\
\hline 77 & Masonry & 3924 & 2173 & 2176 & 3.00 & 3.00 & 8.00 & Damaged \\
\hline 78 & Masonry & 3939 & 2177 & 2178 & 0.50 & 6.00 & 15.00 & Destroyed \\
\hline 79 & Masonry & 3955 & 2181 & 2184 & 2.50 & 6.00 & 16.00 & Damaged \\
\hline 80 & Masonry & 4108 & 2226 & 2233 & 5.50 & 10.00 & 18.00 & Good \\
\hline 81 & Masonry & 4197 & 2295 & 2300 & 4.50 & 6.00 & 7.00 & Good \\
\hline 82 & Masonry & 4306 & 2364 & 2370 & 6.00 & 5.00 & 5.50 & Good \\
\hline
\end{tabular}

Velocities were back calculated on two cross sections along the channel using both the vortex equation and the run-up equation (Johnson and Rodine, 1984; Hungr et al., 1984; Iverson et al., 1994; Jakob et al., 2000; Remaitre et al., 2005a) and multiplied by the cross-sectional area to estimate peak discharge. Velocities ranged from 6.4 to $8.9 \mathrm{~m} \mathrm{~s}^{-1}$; velocities back-calculated with the run-up equation are somehow higher than those obtained with the vortex equation. Peak discharges ranged from 150 to $200 \mathrm{~m}^{3} \mathrm{~s}^{-1}$ (Table 2).

\subsection{Sedimentology and rheology of the 2003 debris flow}

Nine samples of matrix were gathered at several locations both on the two triggering spots (Trois Hommes and Champerousse) and along the main axis of the debris-flow track (Fig. 4). Debris-flow deposits were sampled at 20 and $50 \mathrm{~cm}$ depth; the average weight of the samples was about 50 to $150 \mathrm{~kg}$. The fraction $>20 \mathrm{~mm}$ has been measured and characterized (petrography) in the field. For the fraction $<20 \mathrm{~mm}$, all samples were oven dried and sieved from less than $20 \mathrm{~mm}$ to $0.050 \mathrm{~mm}$. The proportion of fines $(<0.050 \mathrm{~mm})$ was analysed by laser diffractometry. The grain-size distribu- tion obtained on the fraction passing $20 \mathrm{~mm}$ sieve shows a remarkable difference between the debris-flow deposits samples (Fig. 5). The Trois Hommes (TH03) and the Champerousse (CHA03) deposits, sampled in the triggering areas, correspond to granular debris-flows flows deposits; indeed the fraction of fine elements (finer than $0.050 \mathrm{~mm}$ ) did not exceed $10 \%$. The Faucon deposits (FAU03) correspond to muddy debris-flow deposits ( $D_{50}$ varies from 0.15 to $1 \mathrm{~mm}$ ), indeed the clay and silt content ranges from 16 to $33 \%$, and they are sandy clay loam or sandy clay. According to scouring phenomena, proportion of fine elements increases with the distance to the triggering areas. This has been either observed during the 1996 debris-flow event (Remaitre et al., 2005b).

The rheological analyses have been performed for the clay-rich deposits (FAU03_1, FAU03_2, and FAU03_3) with several methods: rheometry, slump tests, flume tests and field estimation. The detailed physical characteristics (including the rheological properties) of the source formations (black marls, moraines, weathered limestones, etc.) can be found in Malet et al. (2003) and Remaitre et al. (2005b). We evaluated the rheological behaviour at different solid fractions (from 37 to 55\%, by volume). The results are compiled in Fig. 6 . 


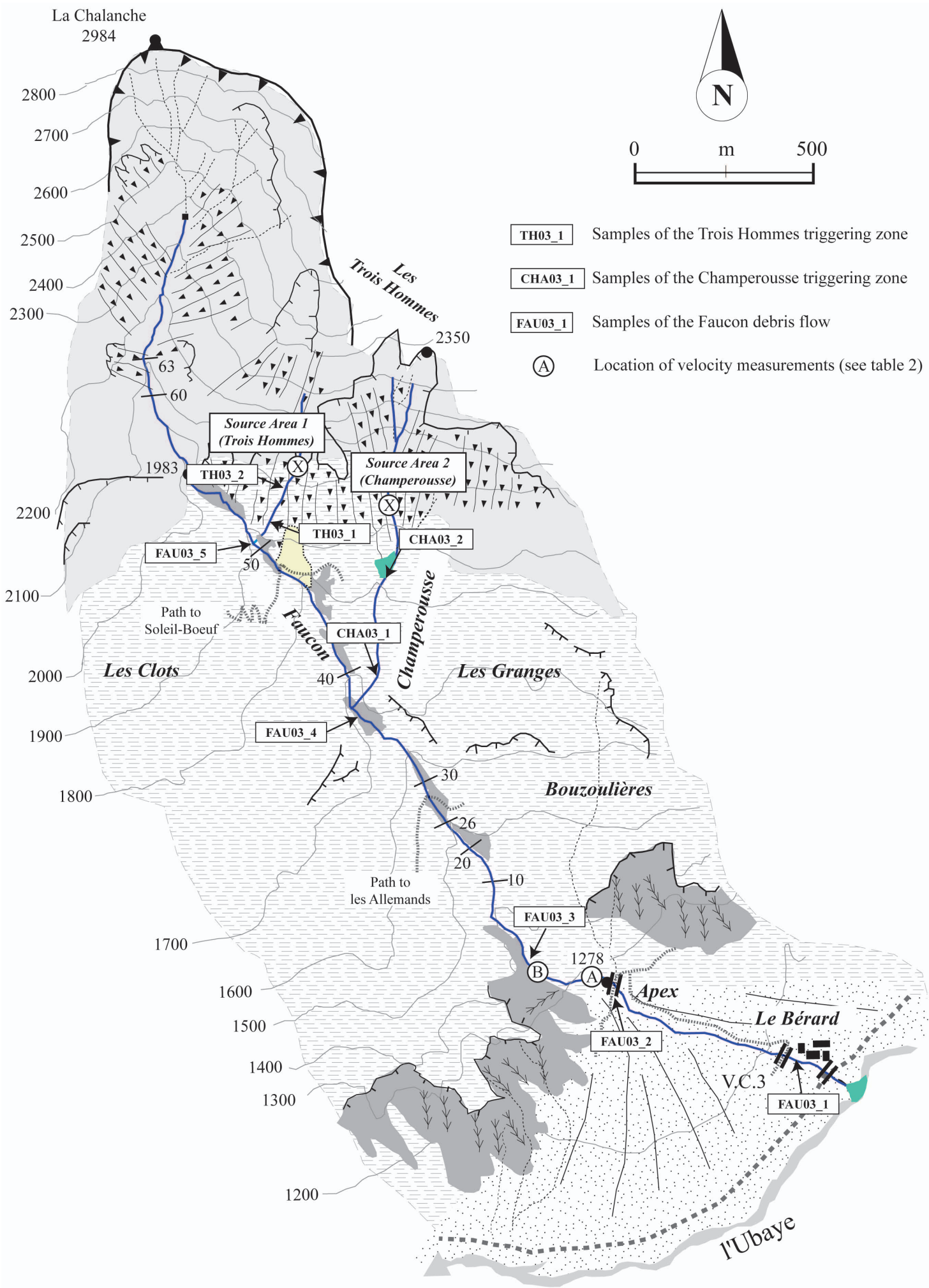

Fig. 4. Location of the 2003 debris-flow deposits samples at the Faucon torrent. 


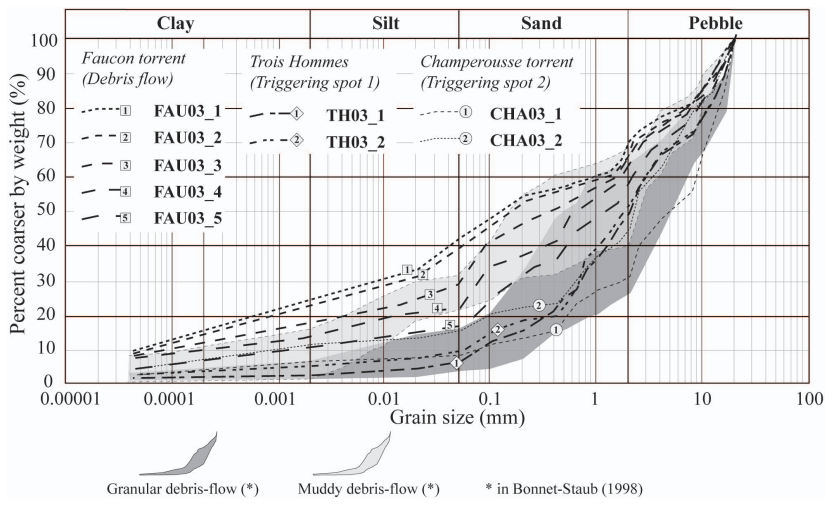

Fig. 5. Grain-size distribution of the 2003 debris-flow deposits.

The material behaves as a viscoplastic fluid, with a shear rate dependent behaviour, as obtained by other authors for clay-rich mixtures at similar stress conditions (e.g. O'Brien and Julien, 1988; Major and Pierson, 1992; Coussot et al., 1996; Sosio et al., 2007). The FAU03 deposit exhibits viscoplastic behaviour for all shearing velocities and is well fit by a Herschel-Bulkley model. Rheological parameters $\left(\tau_{c}\right.$, $\kappa)$ decreased with the total solid concentration by volume (Fig. 6). The yield strength ranged from 1 to $270 \mathrm{~Pa}$ and viscosity from 9 to $71 \mathrm{~Pa}$.

\section{The debris-flow run-out model (JDFM-1D)}

The JDFM-1D debris-flow run-out model has been developed by van Asch (van Asch et al., 2004). The constitutive equation used in the model is a simplified 2-parameters Bingham plastic rheology described mathematically as follows in simple shear geometry:

$\frac{\partial v}{\partial y}=\frac{1}{\eta}\left(\tau-\tau_{0}\right)$

where, $v$ is the velocity $\left(\mathrm{m} \mathrm{s}^{-1}\right), y$ is the depth perpendicular to the velocity (m), $\eta$ is the dynamic viscosity (kPa s), $\tau$ is the shear stress $(\mathrm{kPa})$ and $\tau_{0}$ is the yield strength $(\mathrm{kPa})$. Bingham plastic fluids exhibit linear shear-stress shear-rate behaviour after an initial shear-stress threshold has been reached (Ancey, 2007).

Since the debris-flow has a changing geometry, inter slice forces are not symmetrical like in the infinite slope model. Therefore the shear stress and yield strength in Eq. (1) are calculated with the simplified Janbu equilibrium model (Janbu, 1954; Nash, 1987):

$F^{t}=\frac{\sum\left[c^{\prime} L+\left(W^{t}-\left(U_{\text {normal }}^{t}+U_{\text {excess }}^{t-1}\right)\right) \tan \phi^{\prime}\right] / n_{\alpha}}{\sum W^{t} \tan \alpha}=\left(\frac{\sum S}{\sum T}\right)$

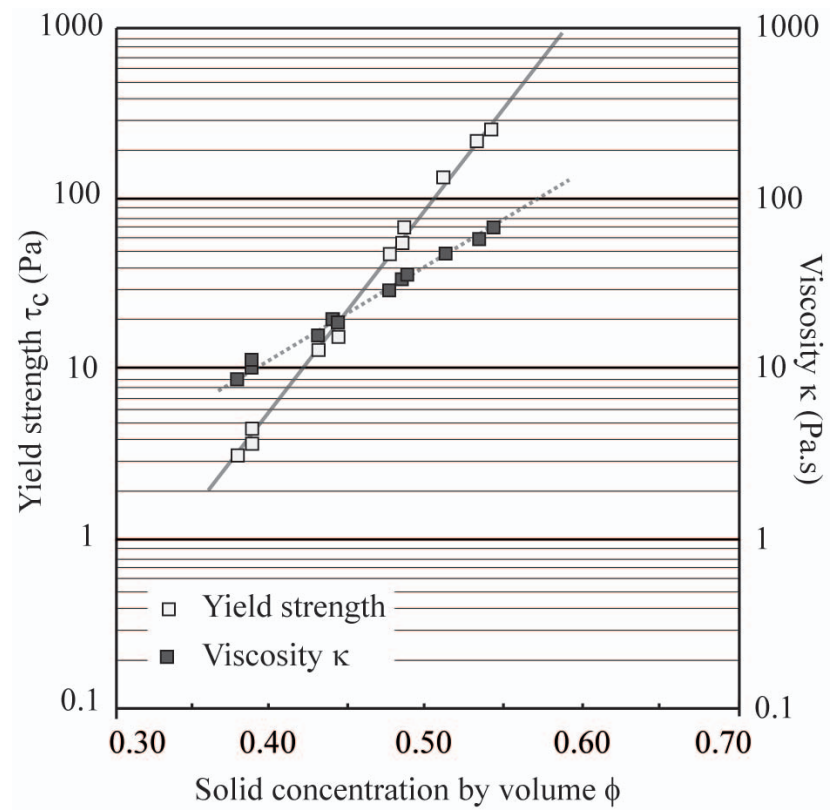

Fig. 6. Empirical relationships relating yield strength and viscosity on varying the solid concentration by volume for the 2003 debrisflow event at the Faucon torrent.

$n_{\alpha}=\cos ^{2} \alpha\left(1+\tan \alpha \frac{\tan \varphi^{\prime}}{F^{t-1}}\right)$

where, $W$ is the weight of an individual slice $j(\mathrm{kN}) ; U$ is the pore water force on the slip surface of slice $j(\mathrm{kN}), c^{\prime}$ is the cohesion $(\mathrm{kPa}), \phi$ ' is the effective friction angle $\left({ }^{\circ}\right), \alpha$ is the slope angle of slice $j\left({ }^{\circ}\right), L$ is the length of the slip surface of slice $j(\mathrm{~m}), S=\tau_{0} L$ is the resisting force of slice $\mathrm{j}(\mathrm{kN})$ and $T=\tau L$ is the mobilized shearing force of slice $\mathrm{j}(\mathrm{kN})$. This stability model satisfies force equilibrium on each slice and moment equilibrium on the whole failure surface (Duncan and Wright, 1980).

In the presented simulation, the width of the slices is $5 \mathrm{~m}$. The Janbu equation delivers the yield strength and the shear stress, which are needed for Eq. (1). Equation (2a) contains $F$ on both sides, which is solved iteratively in the first time step. In the following time steps $F^{t}$ on the left side of Eq. (2) is calculated with $F^{t-1}$ obtained from the former time step and which is substituted for each slice in Eq. (2b) to calculate the right side of Eq. (2a). Assuming a velocity profile, which increases linearly with flow depth, the displacement of mass in $\mathrm{m}^{3} \mathrm{~m}^{-1}$ per times step is given by:

$q=1 / 2 v \Delta t\left(h_{p}+h_{j}\right)$

where, $v$ is the velocity, $\Delta t$ is the time step ( $5 \mathrm{~s}$ in our simulations), $h_{p}$ the thickness of the rigid plug (m) and $h_{j}$ is the total depth of the slice $j(\mathrm{~m})$. 
Table 2. Velocities and peak discharge of the 2003 debris flow.

\begin{tabular}{|c|c|c|c|c|c|c|c|c|c|}
\hline & \multirow[t]{2}{*}{$\begin{array}{l}\text { Cross- } \\
\text { sectional } \\
\text { area } \\
\left(\mathrm{m}^{2}\right)\end{array}$} & \multirow[t]{2}{*}{$\begin{array}{l}\text { Channel } \\
\text { longitudinal } \\
\text { slope } \\
\left({ }^{\circ}\right)\end{array}$} & \multirow[t]{2}{*}{$\begin{array}{l}\text { Radius of } \\
\text { curvature } \\
\text { (m) }\end{array}$} & \multirow[t]{2}{*}{$\begin{array}{l}\text { Banking } \\
\text { angle of } \\
\text { the flow } \\
\left({ }^{\circ}\right)\end{array}$} & \multirow[t]{2}{*}{$\begin{array}{l}\text { Height } \\
\text { of run-up } \\
\text { (m) }\end{array}$} & \multicolumn{2}{|c|}{$\begin{array}{l}\text { Velocity } \\
\left(\mathrm{m} \mathrm{s}^{-1}\right)\end{array}$} & \multicolumn{2}{|c|}{ Peak discharge } \\
\hline & & & & & & Vortex eq. & Run-up & Vortex eq. & Run-up \\
\hline $\mathrm{A}$ & 24.6 & 10 & 22.6 & 5 & 2.6 & 6.4 & 7.1 & 157.1 & 175.7 \\
\hline B & 22.1 & 16 & 24.7 & 12 & 3.9 & 7.8 & 8.9 & 173.3 & 195.8 \\
\hline
\end{tabular}

The thickness of the rigid plug is given by:

$h_{p}=\frac{c L h_{j}}{T-N^{\prime} \tan \varphi^{\prime}}$

$N$ ' is obtained by resolving the forces per slice vertically:

$N^{\prime}=W / \cos \alpha-U-T \tan \alpha$

The routing of the material in a time step is done by a simple mass balance equation:

$\Delta q_{j}=q_{j-1}-q_{j}$

where the slice $j_{-1}$ lies upstream of slice $j$. A zero $\phi$-value in Eq. (2) delivers Bingham behaviour of the material. For the Coulomb viscous flow behaviour a combination of $\mathrm{c}$ - and $\phi$-values (including a $c=0$ condition) can be selected.

A pore pressure ratio $p_{u}$, defined by Eq. (7), is applied for each slice during the run-out:

$p_{u}=\frac{h_{w} \gamma_{w}}{h_{j} \gamma_{s}}$

where, $h_{w}$ is the vertical height of the groundwater $(\mathrm{m}), \gamma_{w}$ is the unit weight of water $\left(\mathrm{kN} \mathrm{m}^{-3}\right), \gamma_{s}$ is the unit weight of saturated material $\left(\mathrm{kN} \mathrm{m}^{-3}\right)$. For a given $\mathrm{p}_{\mathrm{u}}$-value, a pore water force $U$ can be calculated for equation 2 a for each slice as follows:

$U=p_{u} h_{j} \gamma_{s} L$

During run-out, a constant pore pressure ratio or a dissipation of excess pore pressure can be assumed. Assuming that the muddy debris-flow is completely saturated $\left(h_{w}=h_{j}\right.$ in Eq. 7) the amount of excess pore pressure in terms of the pore pressure ratio is:

$p_{u}^{\text {excess }}=p_{u}-\frac{\gamma_{w}}{\gamma_{s}}$

During run-out, dissipation of excess pore pressure is estimated by Therzaghi's theory of one-dimensional consolidation of an open layer (Whitlow, 1995). The fractional dissipation $\left(F_{r}\right)$ of $\mathrm{p}_{\mathrm{u}}$-excess during an elapsed run-out time $t=i$ is given by:

$\stackrel{t=i}{\mathrm{Fr}}=1-\frac{8}{\pi^{2}}\left[e^{-\left(\pi^{2} / 4\right) T_{v}}+\frac{1}{9} e^{-\left(9 \pi^{2} / 4\right) T_{v}}+\frac{1}{25} e^{-\left(25 \pi^{2} / 4\right) T_{v}} \ldots\right]$

where, $T_{v}$ is the dimensionless time factor of onedimensional consolidation and pore water dissipation process. $F_{r}$ has a value between 0 and 1 (=complete dissipation of excess pore pressure).

$T_{v}$ in Eq. (10) is defined as follows:

$T_{v}=\frac{C_{v} t_{i}}{d^{2}}$

where, $t_{i}$ is the elapsed time (s), $d$ is the length of the drainage path that for an open layer equals half the mean thickness of the flow $(\mathrm{m}), C_{v}$ is the coefficient of consolidation $\left(\mathrm{m}^{2} \mathrm{~s}^{-1}\right)$.

For each time step the amount of excess pore pressure is calculated by equation (12):

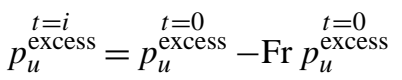

The input parameters (Fig. 7) are the topography of the torrential track, and the characteristics of the initial source material: volume $\left(\mathrm{m}^{3}\right)$, unit weight $\left(\mathrm{KN} \mathrm{m}^{3}\right)$, the internal friction angle $\left({ }^{\circ}\right)$, the cohesion $(\mathrm{kPa})$ and the dynamic viscosity (kPas).

The model has been previously tested on real debris-flows track profiles. For instance, the model has been calibrated and validated on two landslide-induced debris flows at the Super-Sauze mudslide (van Asch et al., 2004).

A scoured volume determined with a semi-empirical approach is added for each cell of the flow prototype at each time step (Fig. 7). According to Rickenmann et al. (2003), we assumed that this scoured volume depends essentially on a kind of integrated mean shear stress of the debris-flow mixture which passed through section of the torrent, and is controlled by the slope gradient, the volume and the density of the mixture which enters this section. Moreover, we considered that scouring occurs if (Eq. 1) the flow height is at least $1 \mathrm{~m}\left(H_{c}\right.$ : critical height) and (Eq. 2) the distance between the debris-flow front $\left(X_{\text {front }}\right)$ and the location of a scoured stretch $(X)$ is less than $100 \mathrm{~m}$. 


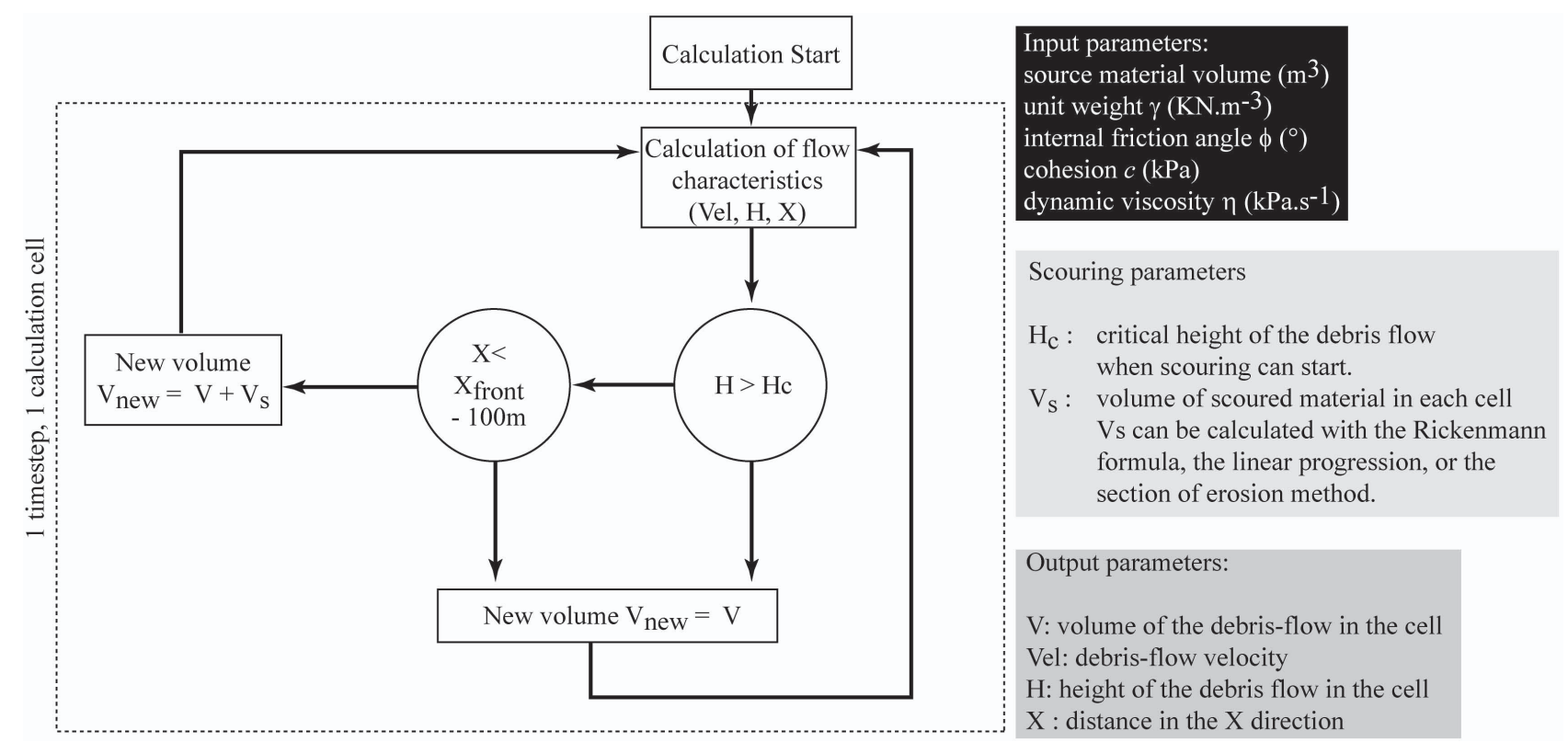

Fig. 7. Characteristics of the JDFM 1D model and of the scouring calculation rules.

The model has been calibrated for the 2003 event before using it for scenario modelling (Fig. 8). Calibrations were carried out on the run-out distance and the flow height. For each model run a $\phi$-value was selected starting with $\phi=0$ (Bingham behaviour). The c- and $\phi$-values were obtained by calibration. The cohesion $(c)$ could be calibrated on run-out distance, while the dynamic viscosity $(\eta)$ could be calibrated on the flow height. With increasing $\phi$-values the dynamic viscosity decreases. This is explained by the overall increase in resistance of the flow due to the dependency of friction on flow depth. Therefore, in order to match the observed flow height the dynamic viscosity has to be lowered. However the calibrated viscosities $(\eta)$ are much higher $(8 \mathrm{kPas})$ than the viscosities measured in the laboratory with parallel-plates rheometrical tests and inclined-plane tests; the maximum viscosity is 0.1 to $0.2 \mathrm{kPa}$ (Remaître, 2006).

\section{Modelling scenarios}

For each modelling test, the same triggering scenario has been used, based on the observations of the Faucon stream after a debris-flow triggered in 2003 (Remaître et al., 2008). A volume of $5000 \mathrm{~m}^{3}$ of material has been considered, which corresponds to one of the source area (Trois Hommes area); indeed it is not possible to choose more than one source area. The 2003 debris-flow event started as a granular flow, bulked increased in fine elements by incorporating marly sediments along the torrential paths and transformed into a muddy debris flow. Such phenomena have been also observed during the 1996 debris-flow event (Remaitre et al., 2005a, b). In the model, the rheological characteristics of the debris-flow material can not be changed during the run-out. Therefore, we considered that the flow exhibits viscoplastic behaviour for the entire simulation. The source area is located at the upper part of the profile (the A point on the Fig. 9) while the check point (the B point on the Fig. 9) location corresponds to the upper part of the fan where the flow-track shows a clear flattening of the slope gradient. The run-out distance is approximately $4000 \mathrm{~m}$. In the model, the check dams influence the intensity of the debris-flow through topographic variations of the flow track (slope angle). For the scenario A, the height of check dams corresponds to the height observed in the field in July 2003. For the scenarios B and C, a $5 \mathrm{~m}$ height has been considered for all the check dams.

Three main run-out scenarios have been tested (Fig. 9):

(1) Scenario A: effect of the check dams on the intensity of the 2003 debris-flow. Two configurations of debrisflow pathway: profile with no check dams (A1), and the profile with the check dams observed and mapped before the 2003 debris-flow event;

(2) scenario B: effect of the location of check dams on the intensity of a debris flow. Three configurations of check dams location: check dams located in the upper part of the torrential pathway (B1), the middle part (B2) and in the lower part (B3);

(3) scenario $C$ : effect of the number of check dams on the intensity of a debris flow. Three configurations of check dams number: 10 check dams (C1), 20 check dams (C2) and 30 check dams (C3). 


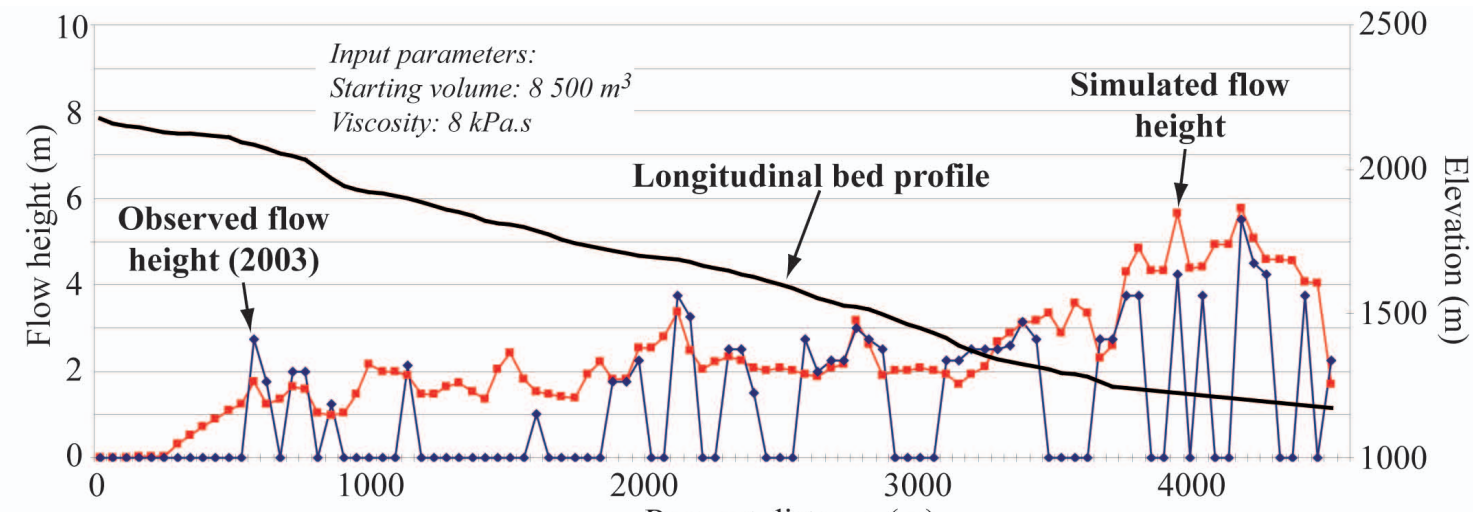

Run-out distance (m)

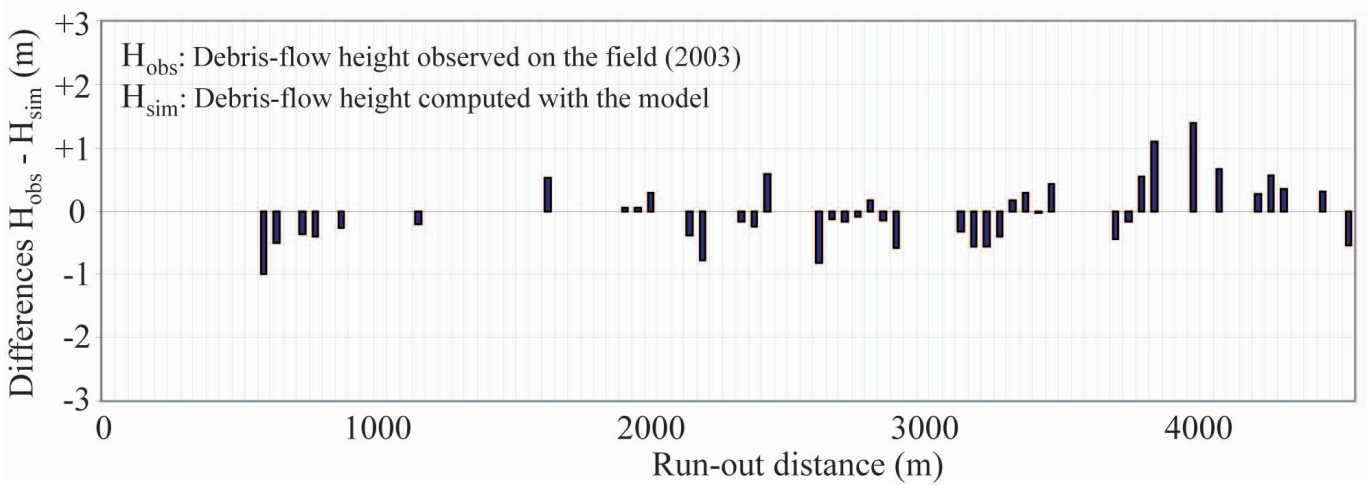

Fig. 8. Calibration of the JDFM-1D code for the 2003 debris-flow event at the Faucon torrent.
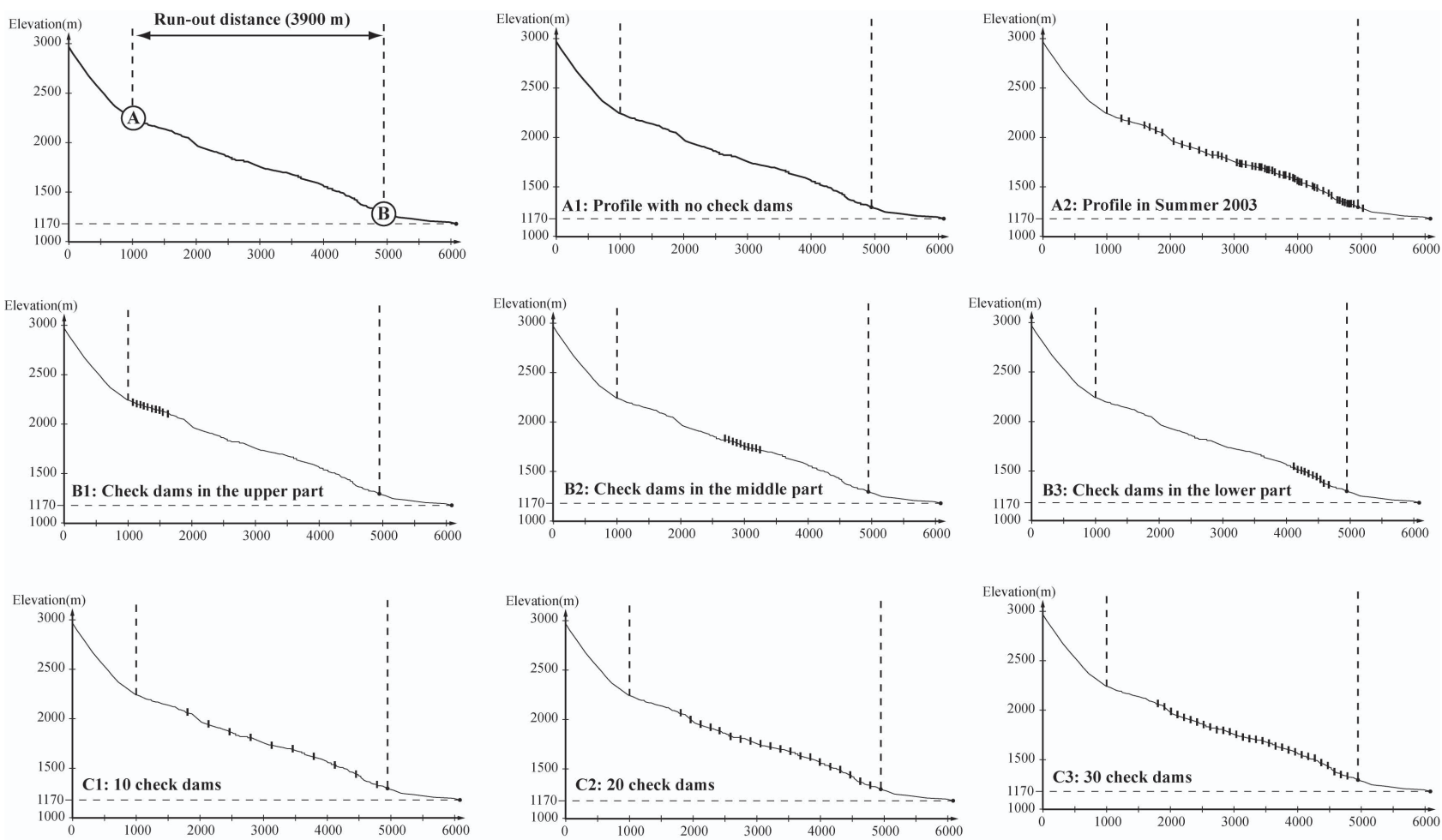

Fig. 9. Settings for the three modelling scenarios. 


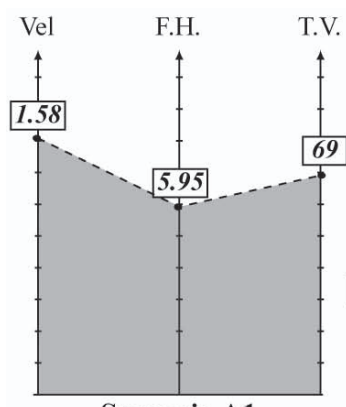

Scenario A1 (No check dams)

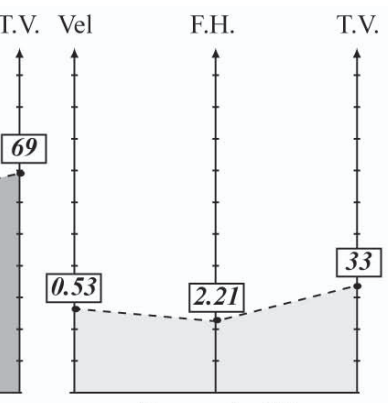

Scenario A2 (with check dams)

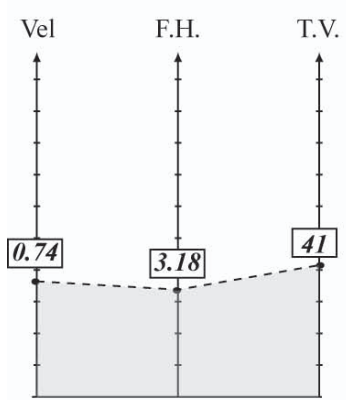

Scenario B1 (Upper part)

(with check dams)
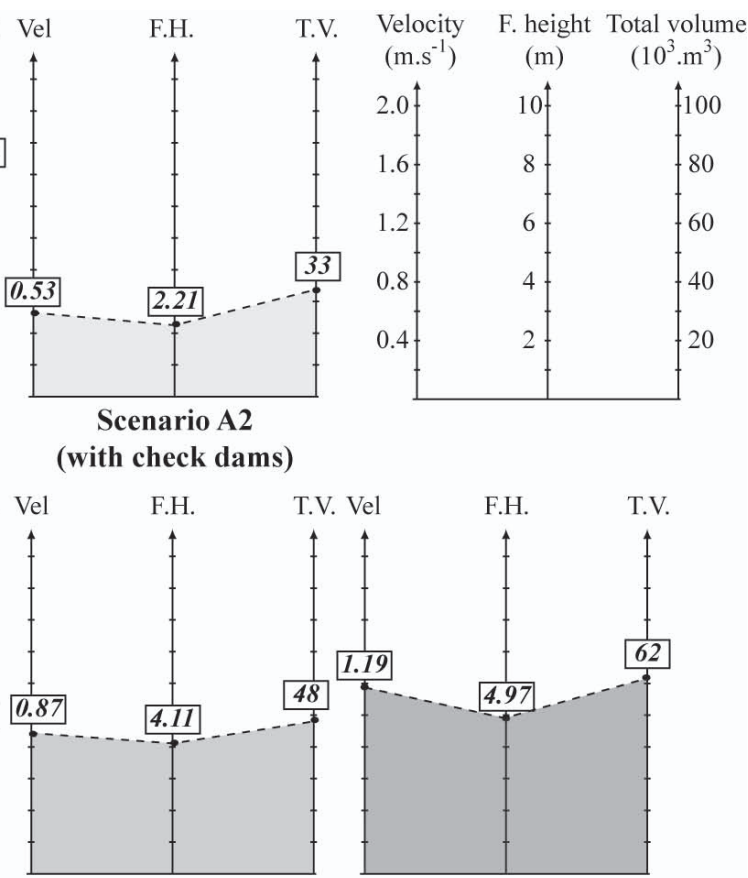

Scenario B2

(Middle part)

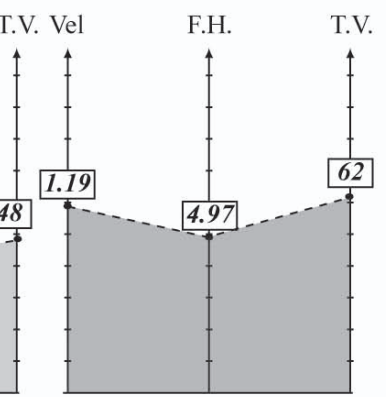

Scenario B3

(Lower part)

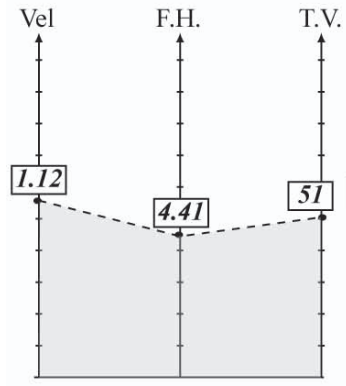

Scenario C1 (10 check dams)

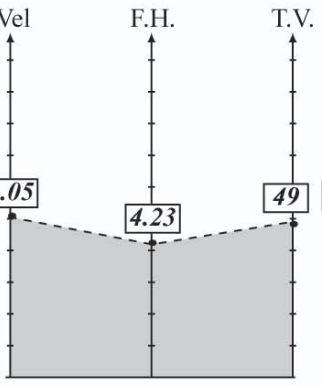

Scenario C2

(20 check dams)

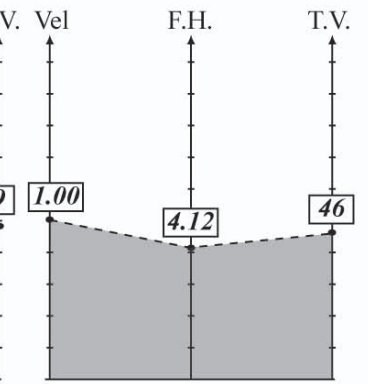

Scenario C3

(30 check dams)

Fig. 10. Comparisons of computed debris-flow intensities (flow velocity, flow height and total volume) using JDFM-1D for three modelling scenarios.

\section{Modelling results}

Different configurations of flow track profile were analysed through a sensitivity analysis. For each configuration, the maximal flow height, the maximal velocity and the total volume of debris where analysed and compared (Fig. 10).

For the scenario A, logically, the intensity of the debris flow is decreasing when the torrent is equipped by check dams. The maximum flow height is decreasing from $5.95 \mathrm{~m}$ (A1: no check dams) to 2.21 (A2: 75 check dams), while the maximum velocity is decreasing from $1.58 \mathrm{~m} \mathrm{~s}^{-1}$ (A1) to $0.53 \mathrm{~m} \mathrm{~s}^{-1}$ (A2). The total volume of the debris-flows is decreasing from $69000 \mathrm{~m}^{3}$ (A1) to $33000 \mathrm{~m}^{3}$ (scenario A2). According to this result, what is the best solution to improve check dams effect on the debris-flow intensity? Authorities should increase the number of check dams (scenarios C)? Or shall they take more attention on some specific area of the debris-flow track (scenarios B)? 
The run-out modelling according the influence of the number of check dams (scenario C) shows a relative regular decrease of the flow intensity. The decrease is particularly strong between the scenario A1 (no check dams) and the scenario $\mathrm{C} 1$ ( 10 check dams): decreasing of the maximal velocity, the maximal flow height and the volume are respectively $29 \%$ ( 1.58 to $1.12 \mathrm{~m} \mathrm{~s}^{-1}$ ), $25 \%$ (5.95 to $4.41 \mathrm{~m}$ ) and $26 \%$ (69000 to $\left.51000 \mathrm{~m}^{3}\right)$; while the decreasing is gently moderate when the number of check dams is increasing (scenarios $\mathrm{C} 1, \mathrm{C} 2$ and $\mathrm{C} 3$ ). For instance, between the $\mathrm{C} 1$ and the $\mathrm{C} 3$ scenarios, decreasing of the maximal velocity, the maximal flow height and the volume are respectively $11 \%$ ( 1.12 to $1.00 \mathrm{~m} \mathrm{~s}^{-1}$ ), $7 \%$ (4.41 to $4.12 \mathrm{~m}$ ) and $10 \%$ (51 000 to $46000 \mathrm{~m}^{3}$ ).

Concerning the scenario $\mathrm{B}$, the comparison of the debrisflow intensity for the three cases (B1, B2 and B3) shows that the location seems to have a strong influence on the debrisflow intensity. Indeed, the differences are significant between the B1 scenario (dams located on the upper part) and the B3 scenario (dams located on the lower part): decreasing of the maximal velocity, the maximal flow height and the volume are respectively $37 \%$ ( 1.19 to $0.74 \mathrm{~m} \mathrm{~s}^{-1}$ ), 36\% (4.97 to $3.18 \mathrm{~m})$ and $33 \%\left(62000\right.$ to $\left.41000 \mathrm{~m}^{3}\right)$.

\section{Discussion and conclusions}

Morphological, kinematical and rheological features of the 2003 debris flow at the Faucon torrent have been used in the present study to first calibrate a viscoplastic run-out model and second to develop a methodology to assess and quantify run-out intensity according to the presence (number, location) or the absence of check dams.

The JFDM-1D model can take into account the amount of material entrained by the flow along the path (scouring) thereby increasing the final volume deposited. According to Rickenmann et al. (2003), we assumed that the intensity of the scouring is function of the integrated mean shear stress of the debris-flow mixture which passed through sections of the torrent, and is controlled by the slope gradient, the volume and the density of the mixture which enters this section. Therefore, breaking the energy of the flow in the earlier stage of the debris-flow event kinematics would reduce the total amount of entrained material.

The modelling sensitivity analysis of the relative influence of, on one hand the number of check dams, and on the other hand the location of the check dams shows some interesting results. The simulation which provides the lowest debrisflow intensity corresponds to the case where the check dams are located at the upper part of the flow track (Scenario B1), near the source area. These results suggest that a relative small number of check dams located near the potential source areas could be very efficient by breaking early the energy of the debris-flow. For this reason, additional river engineering measures could be proposed, such as construction of new check dams in the upper reaches of the Faucon torrent. These conclusions are valid for a debris flow that exhibited a muddy behaviour; some additional modelling tests have to be provided for granular debris-flows.

This new approach opens a new direction for future research. Additionally work remains to be done in order to (i) analyse the influence of other check dam characteristics (height, width) on the debris-flow intensity and (ii) to develop a robust and efficient methodology which can be applied for routine debris-flow hazard assessment.

Acknowledgements. This paper has been supported by the project "Mountain Risks" funded by the European Commission. The authors gratefully thank Gonghui Wang and two anonymous referees for their useful comments.

Edited by: F. Catani

Reviewed by: G. Wang and two anonymous referees

\section{References}

Ancey, C.: Plasticity and geophysical flows: A review, J. NonNewton. Fluid, 142, 4-35, 2007.

Armanini, A. and Scotton, P.: Experimental analysis on the dynamic impact of a debris flow on structures, Proceedings of the international symposium Interpreavent 1992, Bern Switzerland, 6, 107-116, 1992.

Ayotte, D. and Hungr, O.: Calibration of a runout prediction model for debris flows and avalanches, in: Debris-flow Hazards Mitigation: Mechanics, Prediction, and Assessment, Proceedings of the Second International Conference on Debris-flow Hazard Mitigation, Taipei (Taiwan), edited by: Wieczorek, G. F. and Naeser, N. D., Balkema, Rotterdam, 505-514, 2000.

Caine, N.: The rainfall intensity-duration control of shadow landslides and debris flows, Geogr. Ann. A, 62, 23-27, 1980.

Campbell, R. H.: Debris flows originating from soil slips during rainstorms in Southern California, Q. J. Eng. Geol. Hydroge., 7, 339-349, 1974.

Campbell, R. H.: Soil slips, debris flows and rainstorms in the Santa Monica Mountains and vinicity, Southern California, USGS Prof. Paper 851, 51 pp., 1975.

Cannon, S. H. and Ellen, S.: Rainfall conditions for abundant debris avalanches, San Francisco Bay region, California, California Geology, 38(12), 267-272, 1985.

Corominas, J., Remondo, J., Farias, P., Estevao, M., Zézere, J., Diaz de Teran, J., Dikau, R., Schrott, L., Moya, J., and Gonzales, A.: Debris flows, in: Landslide Recognition, edited by: Dikau, R., Brundsen, D., Schrott, L., and Ibsen M.-L., Wiley, Chichester, 161-180, 1996.

Costa, J. E.: Physical geomorphology of debris flows, in: Developments and Applications in Geomorphology, edited by: Costa, J. E. and Fleisher, P. J., Springer-Verlag, Heidelberg, 268-317, 1984.

Coussot, P., Proust, S., and Ancey, C.: Rheological interpretation of deposits of yield stress fluids, J. Non-Newton. Fluid, 66, 55-70, 1996. 
Couvert, B., Lefebvre, B., Lefort, P., and Morin, E.: Etude générale sur les seuils de correction torrentielle et les plages de dépôt, La Houille Blanche, 46(6), 449-456, 1991.

Crozier, M. J. and Eyles, R. J.: Assessing the probability of rapid mass movement, Proceedings of 3rd Australian New Zealand Conference on Geomechanics: 2.47-2.53, N. Z. Institute of Engineers, Wellington, 1980.

D’Ambrosio, D., Iovine, G., Sparato, W., and Miyamoto, H.: A macroscopic collisional model for debris-flows simulation, Environ. Modell. Softw., 22, 1417-1436, 2007.

Deymier, J.-M., Tacnet, J.-M., and Mathys, N.: Conception et calcul de barrages de correction torrentielle. Collection Etudes, Série Equipement pour l'Eau et l'Environnement, Cemagref Editions, 288 pp., 1994.

Duncan, J. M. and Wright, S. G.: The accuracy of equilibrium methods of slope stability analysis, Eng. Geol., 16(1-2), 5-17, 1980.

Godt, J. W. and Coe, J. A.: Alpine debris-flows triggered by a 28 July 1999 thunderstorm in the Central Front Range, Colorado, Geomorphology, 84, 80-97, 2007.

Guinau, M., Vilajosana, I., and Vilaplana, J. M.: GIS-based debris flow source and runout susceptibility assessment from DEM data - a case study in NW Nicaragua, Nat. Hazards Earth Syst. Sci., 7, 703-716, 2007

http://www.nat-hazards-earth-syst-sci.net/7/703/2007/.

Hungr, O., Morgan, G. C., and Kellerhalls, R.: Quantitative analysis of debris torrent hazards for design of remedial measures, Can. Geotech. J., 21, 663-667, 1984.

Hungr, O., Evans, S. G., Bovis, M. J., and Hutchinson, J. N.: A review of the classification of landslides of the flow type, Environmen. Eng. Geosci., 7, 221-238, 2001.

Hürlimann, M., Copons, R., and Altimir, J.: Detailed debris flow hazard assessment in Andorra: A multidisciplinary approach, Geomorphology, 78, 359-372, 2006.

Iovine, G., Di Gregorio, S., and Lupiano, V.: Debris-flow susceptibility assessment through cellular automata modeling: an example from 15-16 December 1999 disaster at Cervinara and San Martino Valle Caudina (Campania, southern Italy), Nat. Hazards Earth Syst. Sci., 3, 457-468, 2003

http://www.nat-hazards-earth-syst-sci.net/3/457/2003/.

Iverson, R. M.: The physics of debris flows, Rev. Geophys., 35, 245-296, 1997.

Iverson, R. M., LaHusen, R. G., Major, J. J., and Zimmerman, C. L.: Debris flows against obstacle and bends: dynamic and deposits, EOS T. Am. Geophys. Un., 75, 1994.

Jakob, M., Anderson, D., Fuller, T., Hungr., O., and Ayotte, D.: An unusually debris flow at Hummingbird Creek, Mara Lake, British Columbia, Can. Geotech. J., 37, 1109-1125, 2000.

Janbu, N.: Application of composite slip surface for stability analysis, European Conference on Stability Analysis, Stockholm, Sweden, 3, 43-49, 1954.

Jibson, R. W.: Debris flows in southern Puerto Rico, in : Landslide processes in Eastern North America and Puerto Rico, edited by: Schultz, A. P. and Jibson, R. W., Geological Society of America Special Paper, 236, 29-55, 1989.

Johnson, A. M. and Rodine, J. R.: Debris flows, in: Slope Instability, edited by: Brundsen, D. and Prior, D. B., Wiley, Chichester, 257-361, 1984.

Johnson, P. A. and McCuen, R. H.: Silt dam design for debris flow mitigation, J. Hydraul. Eng., 115(9), 1293-1296, 1989.
Laigle, D. and Marchi, L.: Example of mud/debris flow hazard assessment, using numerical models, in: Debris-flow Hazards Mitigation: Mechanics, Prediction, and Assessment. Proceedings of the Second International Conference on Debris-flow Hazard Mitigation, Taipei (Taiwan), edited by: Wieczorek, G. F. and Naeser, N. D., Balkema, Rotterdam, 417-424, 2000.

Lumb, P.: Slope failures in Hong Kong, Eng. Geol., 8, 31-65, 1975.

Major, J. J. and Pierson, T. C.: Debris-flow rheology: experimental analyses of fine-grained slurries, Water Resour. Res., 28(3), 841857, 1992.

Malet, J.-P., Remaître, A., Maquaire, O., Ancey, C., and Locat, J.: Flow susceptibility of heterogeneous marly formations. Implications for torrent hazard control in the Barcelonnette basin (Alpesde-Haute-Provence), in : Proceedings of the 3rd International Conference on Debris-Flow Hazard Mitigation: Mechanics, Prediction and Assessment, Davos, Switzerland, edited by: Rickenmann, D. and Chen, L. C., Milpress, Rotterdam, 351-362, 2003.

Miyazawa, N., Tanishima, T., Sunada, K., and Oishi, S.: Debrisflow capturing effect of grid type steel-made sabo dam using 3D distinct element method, in: Proceedings of the 3rd International Conference on Debris-Flow Hazard Mitigation: Mechanics, Prediction and Assessment, Davos, Switzerland, edited by: Rickenmann, D. and Chen, L. C., Milpress, Rotterdam, 527-538, 2003.

Montgomery, D. R. and Dietrich, W. E.: A physically based model for the topographic control on shallow landsliding, Water Resour. Res., 30, 1153-1171, 1994.

Nash, D.: A comparative review of limit equilibrium methods for stability analysis, in: Slope Stability, edited by: Anderson, M. G. and Richards, K. S., John Wiley \& Sons Ltd., 11-77, 1987.

O'Brien, J. S., Julien, P. Y., and Fullerton, W. T.: Two-dimensional water flood and mudflow simulation, J. Hydraul. Eng.-ASCE, 119(2), 244-261, 1993.

Okuda, S., Ashida, K., Gocho, Y., Okunishi, K., Sawada, T., and Yokoyama, K.: Characteristics of heavy rainfall and debris hazard, Natural Disaster Science, 4, 41-55, 1980.

Pierson, T. C.: Erosion and deposition of debris flows at Mount Thomas, North Canterbury, New Zealand, Earth Surf. Proc. Land., 5, 227-247, 1980.

Remaître, A.: Morphologie et dynamique des laves torrentielles: applications aux torrents des Terres Noires dans le bassin de Barcelonnette (Alpes du Sud), Ph.D. thesis, Université de CaenBasse Normandie, 487 pp., 2006.

Remaître, A., Maquaire, O., and Malet, J. P.: Morphology and sedimentology of a complex debris flow in clay-shales basin, Earth Surf. Proc. Land., 30, 339-348, 2005a.

Remaître, A., Malet, J.-P., Ancey, C., Locat, J., and Maquaire, O.: Flow behaviour and runout modelling of a complex debris flow in clay-shales basin, Earth Surf. Proc. Land., 30, 479-488, 2005 b.

Rickenmann, D., Weber, D., and Stepanov, B.: Erosion by debris flows in field and laboratory experiments, in: Proceedings of the 3rd International Conference on Debris-Flow Hazard Mitigation: Mechanics, edited by: Rickenmann, D. and Chen, L. C., Prediction and Assessment, Davos, Switzerland, Milpress, Rotterdam, 883-894, 2003.

Scott, K. M., Vallance, J. W., and Pringle, P. T.: Sedimentology, behaviour and hazards of debris flows at Mount Rainier, Washington, USGS Prof. Paper 1547, 56 pp., 1995.

Sosio, R., Crosta, G. B., and Frattini, P.: Field observations, rheological testing and numerical modelling of a debris-flow event, 
Earth Surf. Proc. Land., 32(2), 290-306, 2007.

Takahashi, T.: Debris flows, Balkema, Rotterdam, 165 pp., 1991. van Asch, T. W. J., Malet, J.-P., Remaître, A., and Maquaire, O.: Numerical modelling of the run-out of a muddy debris flow, The effect of rheology on velocity and deposit thickness along the run-out track, in: Proceedings of the 9th International Symposium on Landslides, edited by: Lacerda, W., Rio de Janeiro, Brazil, 1, 1433-1438, 2004.

VanDine, D. F. and Bovis, M.: History and goals of Canadian debris-flow research, Nat. Hazards, 26(1), 67-80, 2002.
Whitlow, R.: Basic Soil Mechanics, Essex, Longman, 592 pp., 1995.

Wieczorek, G. F.: Effect of rainfall intensity and duration on debris flows in central Santa Cruz Mountains, California, in: Debris flows/Avalanches: Process, Recognition, and Mitigation. Reviews in Engineering Geology, edited by: Costa, J. E. and Wieczorek, G. F., Geological Society of America, 7, 93-104, 1987. 